\title{
CONTRASTING ARBOREAL AND TERRESTRIAL BRYOPHYTES COMMUNITIES OF THE MOUNT HALIMUN SALAK NATIONAL PARK, WEST JAVA
}

\author{
NUNIK S. ARIYANTI and SULISTIJORINI \\ Department of Biology, Faculty of Mathematics and Natural Sciences, \\ Bogor Agricultural University
}

Recipient of BIOTROP Research Grant 2009 / Accepted 30 April 2011

\begin{abstract}
Bryophyte communities were compared between arboreal (trunk bases) and terrestrial habitats in primary forest Mount Halimun Salak National Park, West Java. The communities were analyzed based on species diversity, abundance, and biomass. A total of 150 bryophytes species were identified, including 67 species of mosses (Bryopsida) and 83 of liverworts (Hepaticopsida). Both bryophyte groups varied in diversity and abundance between arboreal and terrestrial communities as well as among different elevations. Species diversity of arboreal habitats (116 species) was higher than that of terrestrial habitats (64 species). Moss species were more abundant in terms of coverage in terrestrial habitats whereas liverworts species were more abundant in arboreal habitats. Species richness in both terrestrial and arboreal habitats decreased towards higher elevation, whereas the abundance increased.
\end{abstract}

Key words: Bryophytes, mosses, liverworts, terrestrial habitat, arboreal habitat

\section{INTRODUCTION}

Bryophytes are frequently neglected due to its small size and their economical value is not much known. However, a recent study (Harris 2008) listed about 150 ethnobotanical species of bryophytes; about 27 percent of those species are used in traditional Chinese medicine including Rhododendron giganteum which is used for treating nervous disorder and cardiovascular disease. This species is also found at Mount Gede Pangrango National Park (Hasan \& Ariyanti 2004).

Bryophytes occupy a wide range of habitats, colonizing various terrestrial substrates, tree trunks and tree canopies. Bryophytes represent important components of forest floor and epiphyte communities in many ecosystems, contributing to forest diversity, structure and ecosystem-level processes. Even bryophytes especially liverworts are abundant and dominant in "cloud" or "mossy" forest.

$\overline{\text { Corresponding author : nuniksa@gmail.com }}$ 
Despite of their traditional medicinal use, bryophytes have a range of important roles to play in the environment. Bryophytes may serve as substrate for other plants and offer shelter to small animals. Changes in epiphytic bryophyte assemblages affect other canopy dwelling biota, such as vascular epiphytes, invertebrates, and especially foraging birds (Sillet 1994; Andrew et al. 2003). The moist environment created by the bryophytes is also quite favorable to the establishment and growth of important groups of microorganisms, such as the nitrogen-fixing blue green algae (Gradstein $e t$ al. 2001). The abundance of liverworts in "cloud" or "mossy" forest is considered an important factor in eliminating the deteriorating effect of heavy rains, including helping to prevent soil erosion and adding to hill stability (Pócs 1980). Bryophytes may serve as potential indicators of climate changes since they are closely assosiated with climatically sensitive habitat and ecosystem (Gignac 2001). In addition, bryophytes have important contributions to forest nutrient cycling, particularly to $\mathrm{N}$-cycling (Longton 1984; Turetsky 2003).

Structure and floristic composition in tropical rain forests vary considerable. The bryophyte flora of tropical rain forest changes significantly with elevation, different taxa often occur in the different forest belts. Bryophytes are very useful indicators of life zones and forest types in tropical mountain regions, since they have relatively modest number of species and genera, very wide geographical ranges, and great variation in biomass (Frahm \& Gradstein 1991).

Studies dealing with diversity and abundance of bryophytes are more frequently referred to temperate region and tropical America region (e.g. McGee \& Kimmerer 2002; Sillet et al. 1995; Acebey et al. 2003; Nöske et al. 2008) than to tropical Asia. Among a few ecological studies of bryophytes in tropical Asia (Frahm 1990; Sporn et al. 2009; Gradstein \& Culmsee 2010) is the diversity and abundance of epiphytic bryophytes assessed in primary and secondary submontane rain forest and cacao agroforestry in Sulawesi (Ariyanti et al. 2008). However, the study did not simultaneously compare the community structures and contributions of both arboreal (epiphytic) and terrestrial bryophyte species in the same ecosystem.

Although Java was considered well inventoried, recent publications dealing with the bryophytes of Java are very few and a modern checklist for mosses is lacking. In contrast, checklists of both mosses and liverworts of others major islands in Malesian region (Borneo, Sulawesi, Philippines) have been provided (Ariyanti \& Gradstein 2007; Ariyanti et al. 2009; Gradstein et al. 2005; Menzel 1988; Tan \& Engel 1986; Tan \& Iwatsuki 1991; Suleiman et al. 2006). Söderström et al. (2010) published a first modern checklist of the liverworts and hornworts of Java and reported more than 600 species for the island. Of these, 479 are accepted species as currently understood based on revision and monographs; the remaining species are little known or of doubtful status, or invalid names.

This research examines bryophyte communities in understory forest of Mount Halimun, West Java, Indonesia. Mosses of Mount Halimun have recently been inventoried (Tan et al., Reinwardtia 12(3): 205-214. 2006) but liverworts and hornworts of the mountain have not yet been reported. There are two primary aims: to assess and compare bryophyte communities in two different substrate type (arboreal and terrestrial) and different altitudes of study sites. 


\section{MATERIALS AND METHODS}

\section{Study Area}

The study took place at Mount Halimun which is located in Mount Halimun Salak National Park, West Java province, Indonesia $106^{\circ} 12^{\prime}$ - $106^{\circ} 45^{\prime}$ East, $06^{\circ} 32^{\prime}-06^{\circ} 55^{\prime}$ South. The four study sites were established at different altitudes: at $1730 \mathrm{~m}$ (site 1), $1250 \mathrm{~m}$ (site 2), 1100.m (site 3) and 1000. $\mathrm{m}$ (site 4).

At each of the four study sites, a plot of $30 \times 30 \mathrm{~m}$ was established. At each plot, terrestrial and arboreal bryophyte diversity were estimated based on species richness and abundance (cover $\mathrm{cm}^{2}$ and frequency \%); the total biomass of the several most dominant species were surveyed; the forest stand and vascular plant characteristics were inventoried. Field samplings were done between July and August 2009.

\section{Terrestrial Sampling}

Methods for terrestrial diversity sampling referred to (Botting et al. 2008) with few modifications. At each plot of $30 \times 30 \mathrm{~m}$, two parallel $30 \mathrm{~m}$ transects were established $10 \mathrm{~m}$ apart, along which the bryophytes were surveyed in $1 \times 1 \mathrm{~m}$ subplot placed at five equi-distant points on the transect. Each species present was recorded and collected for future identification; the coverage ( $\mathrm{cm}^{2}$ of cover) and frequency (\%) of each species occurred in the subplots were recorded based on the quadrat $20 \times 30 \mathrm{~cm}$.

\section{Arboreal Sampling}

Arboreal bryophytes were sampled on five selected trees per plot of $30 \times 30 \mathrm{~cm}$ following Ariyanti et al. (2008) and Botting et al. (2008) with modifications. Selected arboreal sampling trees supporting bryophytes are the trees of more than $20 \mathrm{~cm}$ of diameter breast high. Five quadrats of $20 \times 30 \mathrm{~cm}^{2}$ were placed at different directions of $0-200 \mathrm{~m}$ high of tree trunk. Each species present on the quadrat was recorded or collected for future identification. The coverage $\left(\mathrm{cm}^{2}\right.$ cover) and frequency $(\%)$ of the species in a quadrat of $20 \times 30 \mathrm{~cm}^{2}$ were also recorded.

\section{Data Analysis}

Species identification was done using the following literature: Eddy (1988; 1990; 1996) and Bartram (1039) for the mosses, draft version of Gradstein (2011) for the liverworts. An Analysis of variance (ANOVA) with the main fixed effects of altitude (plots at different altitude) and substrates type (arboreal and terrestrial) were used to evaluate bryophyte communities in the understorey forest with respect to species richness, coverage.

\section{RESULTS}

\section{Species Diversity}

In total, 150 bryophytes species were identified across the terrestrial and arboreal (trunk bases) habitats in the primary forest of the Mount Halimun Salak National Park. They consist of 67 species of mosses (Bryopsida) and 83 species of 
liverwort (Hepaticopsida). In this research we did not found any hornwort species (Antocerotopsida) in the plots. Hornwort commonly occurs in humid, non-forest terrestrial habitats such as river bunk or the open slope of forest margins. Arboreal bryophytes with 116 species found on the base of tree trunks seems more diverse than those of terrestrial bryophytes with 64 species, identified from various substrates such as rotten log, root of trees, rock, and humus. Thirty three species were identified from both terrestrial and arboreal substrates. The lists of species found in the study sites is presented in Appendix 1.

\section{Species richness and abundance}

The total number of species found in the plots of $30 \times 30 \mathrm{~m}$ ranged from 46 species in plot III to 79 species in plot IV. Species richness of arboreal bryophytes in the plots was higher than that of terrestrial bryophytes and varied from 38 to 64 (Fig. 1). Among the arboreal bryophytes, the number of liverworts species in each plot mostly was higher than those of mosses species. On the other hand, the terrestrial bryophytes composed of more mosses than liverworts species.

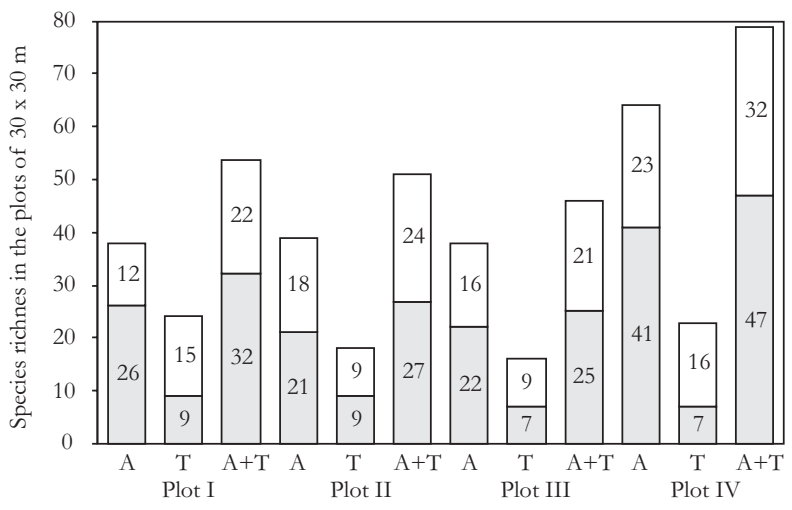

Figure 1. The species number of liverworts $(\mathbf{\square})$ and mosses $(\square)$ on arboreal (A) and terrestrial $(T)$ substrates in plot I, II, III, and IV $(30 \times 30 \mathrm{~m})$ that located at different altitudes

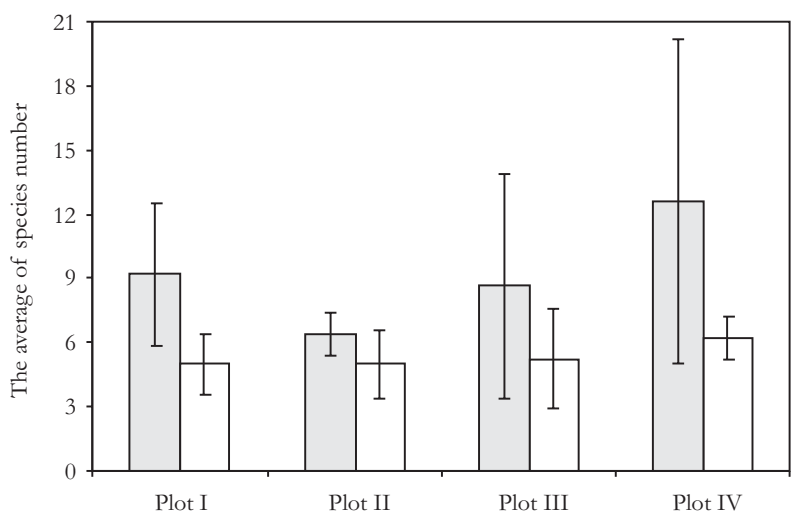

Figure 2. The average of species number of liverworts ( $\square$ ) and mosses ( $\square$ ) of arboreal bryophytes in each tree trunk base in plot $(30 \times 30 \mathrm{~m}) \mathrm{I}, \mathrm{II}, \mathrm{III}$, and IV 
Arboreal and terrestrial bryophytes communities - Nunik S. Ariyanti et al.

Table 1. The six highest coverage $\left(\mathrm{cm}^{2}, \pm\right.$ standard error) of terrestrial and arboreal bryophytes species in quadrates of quadrat $(20 \times 30 \mathrm{~cm})$ in plot I, II, III, and IV. See also Appendix 1.

\begin{tabular}{|c|c|c|c|}
\hline \multicolumn{2}{|c|}{ Terrestrial bryophytes } & \multicolumn{2}{|c|}{ Arboreal bryophytes } \\
\hline Plot / Species & Coverage $\mathrm{cm}^{2}$ & Plot / Species & Coverage $\mathrm{cm}^{2}$ \\
\hline Plot I & & Plot I & \\
\hline Hypnodendron sp. 1 & $60.1 \pm 17.8$ & Syrrhopodon tristichus & $119.7 \pm 61.2$ \\
\hline Trismegistia regida & $48 \pm 33.2$ & Plagiochila frondescens & $95.5 \pm 52.4$ \\
\hline Bazzania sp. 1 & $24.8 \pm 15.5$ & Schistocbila sciurea & $95.3 \pm 50.2$ \\
\hline Pogonatum macropbyllum & $24 \pm 24.0$ & Bazzania tridens & $94.4 \pm 52.6$ \\
\hline Trichosteleum elegantissimum & $19 \pm 14.0$ & Plagiochila dendroides & $85.3 \pm 49.5$ \\
\hline Bazzania vittata & $18.0 \pm 12.4$ & Bazzania vittata & $81.2 \pm 43.7$ \\
\hline Plot II & & Plot II & \\
\hline Callyscostella papillata & $58.6 \pm 29.3$ & Spruceanthus polymorphus & $21.4 \pm 10.7$ \\
\hline Heteroscyphus argutus & $26.9 \pm 15.66$ & Plagiochila sciophyla & $18.8 \pm 12.4$ \\
\hline Lejeunea anisophylla & $18.6 \pm 18.6$ & Heteroscyphus argutus & $17.7 \pm 9.6$ \\
\hline Telanarea neesii & $15.8 \pm 10.9$ & Exostratum blumei & $14.2 \pm 13.5$ \\
\hline Vesicularia reticulata & $15.5 \pm 9.2$ & Leucophanes massartii & $14.2 \pm 10.9$ \\
\hline Distichophyllum schmidtii & $11.8 \pm 8.3$ & Plagiochila javanica & $12.2 \pm 8.5$ \\
\hline Plot III & & Plot III & \\
\hline Callyscostella papillata & $65.8 \pm 57.4$ & Lejeunea anisophylla & $36.0 \pm 18.2$ \\
\hline Heteroscyphus argutus & $30.8 \pm 26.4$ & $\begin{array}{l}\text { Mitth yridium } \\
\text { junquilianum }\end{array}$ & $28.9 \pm 15.9$ \\
\hline Achanthorrinchium papillatum & $30.5 \pm 18.4$ & Radula javanica & $20.0 \pm 9.6$ \\
\hline Vesicularia reticulata & $24.3 \pm 16.3$ & Mitthyridium flavum & $19.4 \pm 10.1$ \\
\hline Lejeunea anisopbylla & $23.3 \pm 18.4$ & $\begin{array}{l}\text { Acanthorrbyncium } \\
\text { papillatum }\end{array}$ & $10.4 \pm 7.0$ \\
\hline Telanarea neesii & $18.6 \pm 15.5$ & Lepidozia wallichiana & $10.2 \pm 10.2$ \\
\hline Plot IV & & Plot IV & \\
\hline Trichosteleum boschii & $33.1 \pm 19.0$ & Syrrhopodon muelleri & $19.6 \pm 13.3$ \\
\hline Achanthorrynchium papillatum & $31.7 \pm 31.7$ & Plagiochila propingua & $14.5 \pm 10.8$ \\
\hline Isopterygium albesce $n s$ & $17.6 \pm 12.5$ & Thysananthus retusus & $13.9 \pm 8.8$ \\
\hline Heteroscyphus argutus & $14.0 \pm 7.1$ & Radula javanica & $13.1 \pm 8.8$ \\
\hline Isopterygium bancanum & $12.1 \pm 9.0$ & Pyrrobryum spiniforme & $12.7 \pm 12.7$ \\
\hline Chaetomitrium lanceolatum & $6.5 \pm 6.5$ & $\begin{array}{l}\text { Acroporium } \\
\text { lamprophyllum }\end{array}$ & $9.4 \pm 9.0$ \\
\hline
\end{tabular}

Bryophytes found at trunk bases (0-2 m) ranged from 11 to 28 species. Each tree trunk base mostly had more liverworts ( 6 - 13 species) than mosses ( 5 - 6 species) (Fig. 2). Though the difference was not significant (ANOVA, $n=5, p=0.05$ ), the number of liverworts and mosses in plot IV was slightly higher than those in other plots. On the contrary, plot II has lower species richness than the other plots.

Species abundance of bryophytes that were estimated based on bryophytes coverage on the substrate showed that the most dominant species of terrestrial bryophytes (indicated by high coverage) is mostly included in the group of mosses, whereas most of arboreal bryophytes having high coverage are the liverworts species. In common, coverage of arboreal species is higher than that of terrestrial species (Table 1).

Though species richness in the plot IV was higher than that of other plots, the coverage of species in plots IV was lower than those in other plots. The arboreal species with the highest coverage in plot IV is Syrrhopodon muelleri which covered about 
BIOTROPIA Vol. 18 No. 2, 2011

Table 2. The species of arboreal and terrestrial bryophytes occurred at least $20 \%$ of sampled quadrates $(\mathrm{n}=25)$ in plot I, II, III, and IV. See also Appendix 1.

\begin{tabular}{|c|c|c|c|}
\hline \multicolumn{2}{|c|}{ Arboreal bryophytes } & \multicolumn{2}{|c|}{ Terrestrial bryophytes } \\
\hline Plot / Species & $\begin{array}{l}\text { Frekuency of } \\
\text { occurance }(\%)\end{array}$ & Plot / Species & $\begin{array}{l}\text { Frekuency of } \\
\text { occurance }(\%)\end{array}$ \\
\hline Plot I & & Plot I & \\
\hline Syrrhopodon tristichus & 80 & $\begin{array}{l}\text { Hypnodendron sp. } 1 \\
\text { Trichosteleum }\end{array}$ & 40 \\
\hline Leucobryum javense & 40 & elegantissimum & 24 \\
\hline Bazzania vittata & 40 & & \\
\hline Plagiochila frondescens & 36 & & \\
\hline Plagiochilion oppositum & 36 & & \\
\hline Schistochila sci urea & 28 & & \\
\hline Plagiochila dendroides & 24 & & \\
\hline Radula javanica & 20 & & \\
\hline Plot II & & Plot II & \\
\hline Lejeunea anisophyla & 28 & Callyscostella papillata & 20 \\
\hline Lopidium trichocladon & 24 & Heteroscyphus argutus & 20 \\
\hline Heteroscyphus argutus & 24 & & \\
\hline Spruceanthus polymorphus & 24 & & \\
\hline Pinnatella sp. 1 & 20 & & \\
\hline Radula multiflora & 20 & & \\
\hline Plot III & & Plot III & \\
\hline Lejeunea anisophyla & 44 & Trichosteleum boschii & 24 \\
\hline Mitthyridium junquilianum & 24 & & \\
\hline Harpalejeunea filicuspis & 24 & & \\
\hline Lejeunea discreta & 24 & & \\
\hline Radula javanica & 24 & & \\
\hline Leucophanes octoblepharoides & 20 & & \\
\hline Mitthyri dium flavum & 20 & & \\
\hline Mitthyridium wallisii & 20 & & \\
\hline Thysananthus spatulistipus & 20 & & \\
\hline Plot IV & & Plot IV & \\
\hline Leucophanes octoblepharoides & 28 & Heteroscyphus argutus & 20 \\
\hline Heteroscyphus argutus & 28 & & \\
\hline Schistochila aligera & 28 & & \\
\hline Cheilolejeunea ceylanica & 24 & & \\
\hline Acroporium lam propbyllum & 20 & & \\
\hline Leucophanes massartii & 20 & & \\
\hline Plagiochila bantamensis & 20 & & \\
\hline Radula javanica & 20 & & \\
\hline
\end{tabular}

$20 \mathrm{~cm}^{2}(3.3 \%)$ of the quadrats. The arboreal species with highest coverage is Syrrbopodon tristichus in plot I that covered $120 \mathrm{~cm}^{2}(20 \%)$ of the quadrates. The six most abundant species in the plot I covered more than $80 \mathrm{~cm}^{2}(13.3 \%)$ area of quadrate, whereas the six most abundant species in others plot cover less than $40 \mathrm{~cm}^{2}(6.7 \%)$ of the quadrates (Table 1).

Distributions of species in the plots are mostly rare. Most species were found in only one of 25 sampled quadrates. Some species are found only twice and others more often in the quadrates (Appendix 1). Only two species were found in more than 10 quadrates. The common species found in at least $20 \%$ of the sampled quadrates are 
listed in Table 2. Liverwort species are more numerous in the arboreal plots (16 species, of 26 species in total), whereas mosses are more numerous in the terrestrial plots ( 4 of 5 in total).

Among the species which have high frequency of occurrence is the epiphytic mosses Syrrhopodon tristichus in plot I which were found at twenty quadrates. The frequency of occurrence of the species is about $80 \%$. Other species were often found in the plot are Leucobryum javense, Bazzania vittata, (both species are epiphytic species in plot I) Hypnodendron sp. 1, and Taxithelium isocladum (both are terrestrial species in plot I and II respectively), all of those species have $40 \%$ of the frequency of occurrence (Table 2).

\section{DISCUSSION}

The bryophyte diversity at natural primary forest of the Mount Halimun Salak National Park Hutan is quite high, it comprises no less than 150 species found across the arboreal (trunk bases) and terestrial habitates. The arboreal diversity is almost as high as in the submontane forest area of Lore Lindu National Park, Central Sulawesi, where Ariyanti et al. (2008) found about 169 bryophytes species on trunk bases in twelve plots. The slightly higher figure for Central Sulawesi is perhaps because the research in Central Sulawesi was conducted in three forest types (natural primary forest, secondary forest, cacao agroforest), while the present research was conducted in primary forest only.

The result of arboreal species (116 species) that were inventoried from 20 sample trees was higher compared with the number of species collected from fewer tree samples and reported for primary submontane $(1100 \mathrm{~m})$, lower montane $(1400 \mathrm{~m})$ and upper montane ( $3250 \mathrm{~m}$ ) forest in Lore Lindu Park, Central Sulawesi, by Gradstein \& Culmsee (2010). Having the same number of tree samples, Ariyanti et al. 2008 collected 112 species from primary submontane $(1000 \mathrm{~m})$ forest in Lore Lindu National Park. The arboreal diversity would have been much higher when the whole trees would have been inventoried. Sporn et al. (2009) collected more epiphitic species than Ariyanti et al. (2008) from the same locations studied by Ariyanti et al. (2008). However, Sporn et al. (2009) sampled the whole trees (the tree trunk and canopy).

When species richness of arboreal and terrestrial bryophyte are compared, the richness of terrestrial bryophytes is lower than that of arboreal species in all the plots. It is not in accordance with the richness of terrestrial bryophytes at the temperate spruce forest which species richness of terrestrial bryophyte exceeds those of arboreal bryophytes (Botting et al. 2008). Tropical rain forests are characterized by high diversity of big tree plants which offers various habitats for epiphytic bryophytes, it perhaps relates to the high diversity of arboreal bryophytes at tropical forest than those at temperate forest in which commonly dominated by several tree species. On the other hand, understorey habitat are covered by canopy forest that determined light intensity penetrating to the ground for bryophytes photosynthesis. More over, the low rate of litter decomposition in the tropical forest may affect the substrates availability for terrestrial bryophytes. The terrestrial substrates in the understorey of primary 
forest in the Mount Halimun Salak National Park were restricted, since the ground was mostly covered by leaf litters, herbs and scrub plants. Terrestrial bryophytes were found growing in mats or clusters at patched substrates such as rotten log, humus, or rock at slightly open area in the forest understorey.

The greater richness of the arboreal habitat than the terrestrial habitat has been discussed by numerous authors (Richards 1984; Gradstein \& Pocs 1989; Frahm 1990; Frahm \& Gradstein 1991; Gradstein et al. 2001; Gradstein \& Culmsee 2010). Richards (1984) mentioned that bryophytes may be absent on undisturbed soil in lowland rain forests and only locally common in montane forests. Gradstein \& Culmsee (2010) also reported that for the arboreal species: liverworts species richness increased toward higher elevation, whereas moss richness decreased.

Bryophytes may represent important components of forest floor and epiphytes communities in the forest ecosystem, contributing high number of species to forest diversity. Vegetation analysis of corridors forest at the Mount Halimun Salak National Park conducted by Sambas and Purwaningsih yield about 27 - 36 species of tree plants in the plot of 0.2 ha (http://www.tnhalimun.go.id/document.php/ document/article/49/38/). Based on this research it appeared that the richness of bryophytes may exceed that of the tree plant. Based on the species number in the plots, it is estimated that bryophytes may contribute about $46-79$ species to the plants community in the forest of the Mount Halimun Salak National Park.

Though the difference was not statistically significant (ANOVA, $n=25, p=0.05$ ), species richness in the plot at higher altitude (plot I, $1730 \mathrm{~m}$ ) tend tobe lower than those at the lower altitudes (plot IV, $1000 \mathrm{~m}$ ). The differences in species richness was also reported by Gradstein and Culmsee (2010) that occurred between lower montane and upper montane rain forest of Lore Lindu National Park in Central Sulawesi. On the other hand, species abundance of bryophytes at higher altitude was higher than those at lower altitudes. The result is in accordance with that of tropical American forest that the coverage of bryophytes increased with the increase of the altitude (Gradstein \& Pocs 1989) and also observed between lower montane and upper montane rain forest of Lore Lindu National Park (Gradstein \& Culmsee 2010)

Some terrestrial species that have highest coverage in the plots were the mosses species of Hypnodendron, Calicostella papillata, dan Trichosteleum boscbii. Those three species were common species, they were often found in the plots (with the frequency of occurrence of about $20 \%$ and they are included in the family Hypnodendraceae, Hookeriaceae, and Sematophyllaceae, respectively. The most dominant arboreal species in terms of coverage are Syrrhopodon tristichus, Syrrhopodon muelleri, Mitthyridium junquilianum (Calymperaceae), Spruceanthus polymorphus, Lejeunea anisopbylla (Lejeuneaceae), Plagiochila frondescens, Plagiochila sciopbyla, and Plagiochila frondescens (Plagiochilaceae). The moss species of Syrrhopodon tristichus and the liverwort species of Lejeunea anisophyla were also the most common species which occurred in $40 \%$ of the 25 quadrate samples. This result is relevant to the bryophytes commonly found in oligophotic habitat such as the understorey forest consisting of many dendroid, feather or bracket-type of mosses and liverworts which are specific of this type habitats. These bryophytes belong to the family of Hookeriaceae, Pterobryaceae, Neckeraceae, Plagiochilaceae, and Lejeuneaceae (Gradstein \& Pocs 1989). 


\section{CONCLUSIONS}

Bryophytes communities at primary forest of the Mount Halimun Salak National Park comprised about 150 species of liverworts and mosses found across various terrestrial and arboreal substrates. The species diversity of arboreal bryophytes at 900 $1730 \mathrm{~m}$ is higher than those of terrestrial bryophytes. Forest at the higher elevation tends to have lower species richness than that at lower elevation. In the contrary, the bryophytes abundances are higher at high elevation compared to that at lower elevation.

\section{ACKNOWLEDGMENTS}

We would like to thank Prof. S. Robbert Gradstein (Museum National D'histoire Naturale, Department Systematique et Evolution) for the valuable suggestions and review of this manuscript. Indah Wahyuni, Dian Apriani, Marinda Sari Sofiyana, and Saiful Bachri assisted us with collecting samples in the field. Funding for this study was provided by research project of DIPA-BIOTROP DIKTI 2009.

\section{REFERENCES}

Acebey C, Gradstein SR, Kromer T. 2003. Species richness and habitat diversivication of bryophytes in submontane rain forest and fallows in Bolivia. Journal of Tropical Ecology, 18: 1-16.

Andrew NR, Rodgerson L, Dunlop M. 2003. Variation in invertebrate - bryophyte communitiy structure at different spatial scales along altitudinal gradients. Journal of Biogeography, 30: 731-746.

Ariyanti NS, Bos MM, Kartawinata K, Tjitrosoedirdjo SS, Guhardja E, Gradstein SR. 2008. Bryophytes on tree trunks in natural forests, selectively logged forests and cacao agroforests in Central Sulawesi, Indonesia. Biological Conservation, 141:2516-2527.

Aryanti NS, Gradstein SR, Sporn SG, Angelika E, Tan BC. 2009. Catalogue of the bryophytes of Sulawesi, Suppplement 1. Blumea, 54:287-289.

Aryanti NS, Gradstein SR. 2007. Wallace's line and the distribution of the liverworts of Sulawesi. Cryptog. Bryol. 28: 3-14.

Bartram EB. 1939. The Philippine Journal of Science. Vol. 68. Manila: Bureau of Printing.

Botting RS, Campbell J, Fredeen AL. 2008. Contrasting arboreal and terrestrial macrolichen and bryophyte communities in old-growth sub-boreal spruce forests of central British Columbia. The Bryologist, 111(4): 607-619

Eddy A. 1988. A Handbook of Malesian Mosses. Vol. 1, Sphagnales to Dicranales. London: British Museum.

Eddy A. 1990. A Handbook of Malesian Mosses. Vol. 2, Leucobryaceae to Buxbaumiaceae. London: The Natural History Museum.

Eddy A. 1996. A Handbook of Malesian Mosses. Vol. 3, Splachnobryaceae to Leptostomataceae. London: The Natural History Museum.

Frahm JP, Gradstein SR. 1991. An altitudinal zonation of tropical rain forest using bryophytes. Journal of Bryogeography. 18: 75-78.

Frahm JP. 1990. The ecology of epiphytic bryophytes of Mt. Kinabalu, Sabah (Malaysia). Nova Hedwigia, 51: 121-132. 
BIOTROPIA Vol. 18 No. 2, 2011

Gignac LD. 2001. Bryophytes as indicators of climate change. The Bryologist, 104: 410 - 420.

Gradstein SR, Churchill SP, Salazar AN 2001. Guide to the bryophytes of tropical America. New York: Memoirs of the New York Botanical Garden, 86: 1-577.

Gradstein SR, Culmsee H. 2010. Bryophytes diversity on tree trunks in montane forests of Central Java. Tropical Bryology, 31:95-105

Gradstein SR, Pocs T. 1989. Bryophytes. In: Lieth H, Werger MJA (eds). Tropical rain forest ecosystems. Amsterdam: Elsevier Science Publishers B.V., p. 311-325.

Gradstein SR, Tan B, King C, Zhu RL, Drubert C, Pitopang R. 2005. A Catalogue of the Bryophytes of Sulawesi, Indonesia. Journal of the Hattori Botanical Laboratory, 98: 213-257.

Gradstein SR. 2011. Guide to the Liverworts and Hornworts of Java. Bogor: SEAMEO BIOTROP.

Harris ESJ. 2008. Ethnobryology: traditional uses and folk classification of bryophytes. The Bryologist, 111 (2): 169-217.

Hasan M, Ariyanti NS. 2004. Mengenal Bryophyta (Lumut) di Taman Nasional Gede Pangrango. Cibodas: Balai Taman National Gunung Gede Pangrango.

Longton RE. 1984. The role of bryophytes in terrestrial ecosystems. Journal of the Hattori Botanical Laboratory, 55: $147-163$

McGee GG, Kimmerer RW. 2002. Forest age and management effect on epiphytic bryophyte communities in Adirondack northern hardwood forest, New York, USA. Canadian Journal of Forest Research, 32: 1562-1576.

Menzel M. 1988. Annotated Catalogue of the Hepaticae and Anthocerotae of Borneo. Journal of the Hattori Botanical Laboratory, 65: 145-206

Nöske N, Hilt N, Werner F, Brehm G, Fiedler K, Sipman HJ, Gradstein SR. 2008. Disturbance effects on diversity in montane forest of Ecuador: sessile epiphytes vs. mobile moths. Basic and Applied Ecology.

Pócs T. 1980. The epiphytic biomass and its effect on the water balance of two rain forest types in the Uluguru Mountains (Tanzania, East Africa). Acta Botanica Academiae Scientiarum Hungaricae, 26:143-167.

Richards PW. 1984. The Ecology of Tropical Forest Bryophytes. In: Schuster RM. (ed.) New Manual of Bryology, Nichinan: Hattori Botanical Laboratory, p. 1233-1270.

Sillet TS. 1994. Foraging ecology of epiphyte-searching insectivorous birds in Costa Rica. Condor, 96: 863-877.

Sillett S, Gradstein SR, Griffin D. 1995. Bryophyte diversity of Ficus tree crowns from cloud forest and pasture in Costa Rica. The Bryologist, 98: 251-260.

Söderström L, Gradstein SR, Hagborg A. 2010. A checklist of the hornworts and liverworts of Java. Phytotaxa, 9: 53-149.

Sporn SG, Bos MM, Keßler M, Gradstein SR. 2009. Vertical distribution of epiphytic bryophytes in an Indonesian rainforest. Biodiversity and Conservation, 19: 745-760.

Suleiman M, Akiyama M, Tan BC. 2006. A revised catalogue of Mosses reported from Borneo. Journal of the Hattori Botanical Laboratory, 99:107-183.

Tan BC et al. 2006. Mosses of Gunung Halimun National Park, West Java, Indonesia. Reindwartia, (12): 205-214.

Tan BC, Engel JJ. 1986. An annotated checklist of Philippine Hepaticae. Journal of the Hattori Botanical Laboratory, 60: 283-355.

Tan BC, IwatsukiZ. 1991. A new Annotated Philippine Moss Checklist. Harvard Papers Botany, 3:1-64.

Turetsky MR. 2003. The Role of Bryophytes in Carbon and Nitrogen Cycling. The Bryologist, 106(3):395-409. 
Arboreal and terrestrial bryophytes communities - Nunik S. Ariyanti et al.

Appendix 1. Alphabetical list of arboreal and terrestrial bryophyte species collected in the plots. $\mathrm{a}=\operatorname{arboreal} ; \mathrm{t}=$ terrestrial; + = present; - = absent.

\begin{tabular}{|c|c|c|c|c|c|}
\hline Species & Habitat & Plot I & Plot II & Plot III & Plot IV \\
\hline \multicolumn{6}{|l|}{ Mosses: } \\
\hline Acanthorrbyncium papillatum & $\mathrm{a}, \mathrm{t}$ & - & - & + & - \\
\hline Acroporium diminutum & $\mathrm{a}, \mathrm{t}$ & + & - & + & + \\
\hline Acroporium bamulatum & $\mathrm{t}$ & + & - & - & - \\
\hline Acroporium lamprophyllum & $\mathrm{a}, \mathrm{t}$ & + & + & + & + \\
\hline Acroporium rufum & $\mathrm{a}, \mathrm{t}$ & + & - & + & + \\
\hline Acroporium sec undum & $\mathrm{a}$ & + & - & - & - \\
\hline Acroporium sigmatodontium & $\mathrm{a}, \mathrm{t}$ & + & - & - & + \\
\hline Callyscostella papillata & $\mathrm{t}$ & - & + & - & + \\
\hline Chaetomitrium lanceolatum & $\mathrm{t}$ & - & - & - & + \\
\hline Dicranoloma blumii & $\mathrm{t}$ & - & + & - & - \\
\hline Dicranoloma braunii & $\mathrm{a}, \mathrm{t}$ & + & - & - & + \\
\hline Dicranoloma brevisetum & $\mathrm{a}, \mathrm{t}$ & + & + & - & + \\
\hline Distichophyllum schmidtii & $\mathrm{t}$ & - & + & - & - \\
\hline Distichophyllum sp. 1 & $\mathrm{t}$ & + & - & - & + \\
\hline Ectropothecium sp. 1 & $\mathrm{t}$ & + & - & + & - \\
\hline Exostratum blumei & $\mathrm{a}, \mathrm{t}$ & - & + & - & + \\
\hline Fissiden crassinervis var. laxus & $\mathrm{t}$ & - & - & - & + \\
\hline Fissidens gedehensis & a & - & + & - & - \\
\hline Fissidens bollianus & $\mathrm{a}, \mathrm{t}$ & - & + & - & - \\
\hline Floribundaria floribunda & $\mathrm{a}, \mathrm{t}$ & - & + & - & - \\
\hline Himantocladium plumula & a & - & - & - & + \\
\hline Homaliodendron flabellatum & a & - & + & - & - \\
\hline Homaliodendron javanicum & a & - & - & - & + \\
\hline Hypnaceae sp. 1 & $\mathrm{t}$ & - & + & - & - \\
\hline Hypnodendron sp. 1 & $\mathrm{t}$ & + & - & - & - \\
\hline Isopterygium albescens & $\mathrm{a}, \mathrm{t}$ & + & - & + & + \\
\hline Isopterygium bancanum & $\mathrm{a}, \mathrm{t}$ & - & - & - & + \\
\hline Isopterygium minu $\quad$ tirameum & $\mathrm{a}, \mathrm{t}$ & + & - & - & + \\
\hline Leucobryum bowringii & $\mathrm{a}$ & - & - & - & + \\
\hline Leucobryum candidum & $\mathrm{t}$ & - & - & - & + \\
\hline Leucobryum javense & $\mathrm{a}, \mathrm{t}$ & + & + & + & + \\
\hline Leucobryum juniperoideum & $\mathrm{a}$ & - & - & + & - \\
\hline Leucophanes massartii & $\mathrm{a}, \mathrm{t}$ & - & + & + & + \\
\hline Leucophanes octoblepharoides & $\mathrm{a}, \mathrm{t}$ & - & + & + & + \\
\hline Lopidium $\quad$ sp. 1 & $\mathrm{a}$ & - & - & - & + \\
\hline Lopidium struthiopteris & a & - & + & - & - \\
\hline Lopidium trichocladon & a & - & + & - & - \\
\hline Mittbyridium flavum & a & - & - & + & - \\
\hline Mitthyridium junquilianum & $\mathrm{a}, \mathrm{t}$ & - & - & + & - \\
\hline Mitthyridium wallisii & $\mathrm{a}, \mathrm{t}$ & - & - & + & - \\
\hline Neckera tjibodensis & $\mathrm{a}$ & - & - & - & + \\
\hline Pelekium velatum & $\mathrm{a}, \mathrm{t}$ & - & + & - & - \\
\hline Pinnatella anac amptolepis & $\mathrm{a}$ & - & + & - & - \\
\hline Pinnatella cf. ambigua & a & - & - & - & + \\
\hline Pinnatella microptera & a & - & + & - & - \\
\hline Pinnatella sp. 1 & a & - & + & - & - \\
\hline Pogonatum macrophylum & $\mathrm{t}$ & + & - & - & - \\
\hline Pterobryopsis gedehensis & $\mathrm{a}$ & - & - & - & + \\
\hline Pyrrobryum medium & a & - & + & - & - \\
\hline Pyrrobryum spiniforme & a & + & + & - & + \\
\hline
\end{tabular}


BIOTROPIA Vol. 18 No. 2, 2011

Appendix 1. Continued

\begin{tabular}{|c|c|c|c|c|c|}
\hline Species & Habitat & Plot I & Plot II & Plot III & Plot IV \\
\hline Symphyso dontella attenuatula & $\mathrm{a}$ & - & - & - & + \\
\hline Symphysodontella cylindrica & a & - & - & - & + \\
\hline Syrrbopodon albovaginatus & $\mathrm{a}$ & - & - & + & - \\
\hline Syrrbopodon muelleri & a & - & - & + & + \\
\hline Syrrbopodon prolifer & $\mathrm{a}$ & - & - & + & - \\
\hline Syrrhopodon tristichus & $a, t$ & + & - & + & - \\
\hline Taxithelium instratum & $\mathrm{a}$ & - & - & - & + \\
\hline Taxithelium is ocladum & $\mathrm{t}$ & + & - & - & - \\
\hline Trichosteleum boschii & $\mathrm{t}$ & - & - & + & + \\
\hline Trichosteleum elegantissimum & $\mathrm{a}, \mathrm{t}$ & + & - & + & - \\
\hline Trimegistia calderensis & $\mathrm{a}$ & + & - & - & - \\
\hline \multicolumn{6}{|l|}{ Liverworts: } \\
\hline Acromastigum divaricatum & $\mathrm{a}$ & + & - & + & - \\
\hline Aneura pinguis & $\mathrm{t}$ & - & + & - & - \\
\hline Arcbilejeunea planiuscula & $\mathrm{a}$ & - & - & - & + \\
\hline Bazzania intermedia & $\mathrm{a}$ & + & + & - & + \\
\hline Bazzania sp. 1 & $\mathrm{a}$ & - & - & - & + \\
\hline Bazzania sp. 2 & a & - & - & + & - \\
\hline Bazzania sp. 3 & $\mathrm{a}$ & - & - & - & + \\
\hline Bazzania sp. 4 & $\mathrm{a}$ & + & - & - & - \\
\hline Bazzania tridens & $\mathrm{a}$ & + & - & + & + \\
\hline Bazzania vittata & $\mathrm{a}, \mathrm{t}$ & + & + & + & - \\
\hline Bazzania wallisiana & $\mathrm{a}$ & + & - & - & - \\
\hline Calypogaea goebelii & a & + & - & - & - \\
\hline Ceratolej eunea belangeriana & $\mathrm{a}$ & - & - & - & + \\
\hline Cheilolejeunea ceylanica & $\mathrm{a}, \mathrm{t}$ & - & - & + & + \\
\hline Cheilolejeunea imbricata & $\mathrm{a}$ & - & - & + & + \\
\hline Cheilolejeunea longiloba & a & + & - & - & + \\
\hline Chiloscyphus minor & a & - & - & - & + \\
\hline Chiloscyphus muricatus & a & - & - & - & + \\
\hline Cololejeunea sp. 1 & $\mathrm{t}$ & - & - & + & - \\
\hline Drepanolejeunea angus tifolia & a & + & - & - & - \\
\hline Drepanolejeunea ternatensis & a & + & - & + & - \\
\hline Frullania apiculata & a & - & - & + & + \\
\hline Harpalejeunea filicuspis & a & - & - & + & - \\
\hline Harpalejeunea filicuspis & $\mathrm{t}$ & - & - & + & - \\
\hline Herbertus dricanus & $\mathrm{a}$ & + & - & - & - \\
\hline Heteroscyphus argutus & $a, t$ & - & + & + & + \\
\hline Heteroscyphus coalitus & $\mathrm{t}$ & - & + & - & - \\
\hline Heteroscyphus succulenthus & $a, t$ & - & + & - & + \\
\hline Heteroscyphus zollingeri & $\mathrm{t}$ & + & - & - & + \\
\hline Jubula sp. 1 & $\mathrm{t}$ & + & - & - & - \\
\hline Kurzia gonyotricha & $\mathrm{a}$ & + & - & - & - \\
\hline Lejeunea anisophyla & $a, t$ & + & + & + & + \\
\hline Lejeunea discreta & $\mathrm{a}$ & + & - & + & + \\
\hline Lejeunea eifigri & a & - & + & - & - \\
\hline Lejeunea exilis & $\mathrm{a}$ & - & - & - & + \\
\hline Lejeunea obscura & $\mathrm{a}, \mathrm{t}$ & - & + & + & + \\
\hline Lejeunea punctiformis & $\mathrm{a}$ & - & - & - & + \\
\hline Lejeunea sordida & a & - & - & + & + \\
\hline Lejeunea sp. 1 & a & - & + & + & - \\
\hline Lepidolejeunea bidentula & $\mathrm{a}$ & - & - & + & - \\
\hline
\end{tabular}


Arboreal and terrestrial bryophytes communities - Nunik S. Ariyanti et al.

Appendix 1. Continued

\begin{tabular}{|c|c|c|c|c|c|}
\hline $\begin{array}{c}\text { Species } \\
\end{array}$ & Habitat & Plot I & Plot II & Plot III & Plot IV \\
\hline Lepidolejeunea integristipula & $\mathrm{a}$ & - & - & - & + \\
\hline Lepidozia basskarliana & $\mathrm{a}$ & + & - & - & - \\
\hline Lepidozia trichodes & $\mathrm{a}$ & - & + & - & - \\
\hline Lepidozia wallicbiana & $\mathrm{a}, \mathrm{t}$ & + & - & + & - \\
\hline Lenjenea anisophyla & $\mathrm{a}$ & - & + & - & - \\
\hline Lophocolea bidentata & $a, t$ & - & - & + & + \\
\hline Lophocolea minor & $\mathrm{t}$ & - & + & - & - \\
\hline Lopholejeunea eulopha & a & - & - & - & + \\
\hline Lopholejeunea borticola & a & - & - & - & + \\
\hline Lopholejeunea nigricans & a & - & - & - & + \\
\hline Lopholejeunea subfus $\quad$ ca & $\mathrm{a}$ & - & - & - & + \\
\hline Lopholejeunea zollingeri & a & + & - & - & + \\
\hline Mastigolejeunea auriculata & $\mathrm{a}$ & - & + & - & - \\
\hline Metalejeunea cuculata & $\mathrm{a}$ & - & - & - & + \\
\hline Metzgeria leptoneura & $\mathrm{a}$ & + & - & - & - \\
\hline Metageria $\quad$ sp. 1 & a & - & - & - & + \\
\hline Plagiochila bantamensis & a & - & + & - & + \\
\hline Plagiochila dendroides & a & + & + & - & - \\
\hline Plagio chila frondescens & a & + & + & - & + \\
\hline Plagiochila javanica & $\mathrm{a}$ & - & + & - & + \\
\hline Plagiocbila junghunbiana & $\mathrm{a}, \mathrm{t}$ & - & + & + & + \\
\hline Plagiochila obtusa & a & - & - & - & + \\
\hline Plagiocbila parvifolia & $\mathrm{t}$ & - & - & - & + \\
\hline Plagiochila pleurata & $\mathrm{a}$ & - & - & + & - \\
\hline Plagiocbila propingua & $\mathrm{a}$ & + & - & - & + \\
\hline Plagiocbila sciophyla & $\mathrm{a}, \mathrm{t}$ & + & + & - & + \\
\hline Plagiochilion oppositum & $\mathrm{a}$ & + & - & - & + \\
\hline Pticanthus striatus & $\mathrm{a}$ & - & + & - & - \\
\hline Radula javanica & $\mathrm{a}$ & + & - & + & + \\
\hline Radula multiflora & a & - & + & - & + \\
\hline Radula retroflexa & a & - & + & + & + \\
\hline Riccardia sp. 1 & $\mathrm{t}$ & - & + & - & - \\
\hline Schistocbila aligera & $\mathrm{a}$ & - & - & - & + \\
\hline Scbistochila doriae & a & - & + & - & - \\
\hline Schistochila sciurea & a & + & - & - & - \\
\hline Spruceantbus polymorphus & $\mathrm{a}$ & - & + & - & - \\
\hline Telenarea neesii & $\mathrm{a}, \mathrm{t}$ & + & + & - & + \\
\hline Thysananthus retusus & $\mathrm{a}$ & - & - & - & + \\
\hline Thysananthus spatulistipus & $\mathrm{a}$ & - & - & + & + \\
\hline Trichocolea tomentella & $\mathrm{a}, \mathrm{t}$ & + & - & - & + \\
\hline Zoopsis liukiuensis & $\mathrm{t}$ & + & - & - & - \\
\hline
\end{tabular}

